\title{
甲状腺疾患と咽嶦頭異常感
}

\author{
戸田 雅点・北野 康雄* *太田 文彦*
}

\section{Relationship of Thyroid Disorders and}

\author{
Foreign-Body Sensation in the Throat
}

\author{
Masakatsu Toda \\ (Noguchi ENT Clinic)

\section{Yasuo Kitano and Fumihiko Ohta} \\ (Kinki University)
}

A statistical investigation was carried out on 1008 cases of thyroid disorders and 1540 cases of foreign-body sensation in the throat (foreign-body sensation). There were 112 men and 896 women in the thyroid disorder group, 596 men and 944 women in the foreign-body sensation group. Most of patients in both groups were between 30 and 50 years old. Our findings strongly suggest that there are much relationship of thyroid disorders (especially chronic thyroiditis) and foreigh-body sensation, and that conbination therapy of anti-inflammatory enzyme, minor tranquillizer and thyroid hormon (T4) is more effective in patients with chronic thyroiditis than only antiinflammatory enzyme and minor tranquillizer.

Key words: foreign-body sensation, thyroid disorders, chronic thyroiditis

\section{はじめに}

耳鼻咽唆科の医们が，日常外来において，咽 喉頭異常感を訴える患者を診祭する機会は最近 ではそんなに珍しくないむのである。にあかか わらず咽喉頭異常感を訴元る患者を実際に㟝療 することは，なかなかに難しいものであり，治 痛せしめるとなれば相当の困難を伴うことが度 々である，乙れは咽唤頭異常感の成因が多岐に わたっているてと，また成因が必ずし屯単一之 は限らないてと，そしてそのために治療におい ても対症療法のみでは効果がないことが多く, それぞれの成因に対しての加療が必紧となって
くること，そのうえこれらの患者の中には悪性 腫晹をはじめとした重篤な器質的灾患をあつも の屯含まれているなど問題点が多いためであ る. これまで咽喉頭珙常感の成因について多く の砸究が行われており 小 $^{1214}$, 近年本邦におい

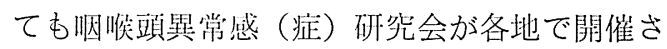
れていて, 発現機序についてあより詳細に研䒚 されている。しかしながらまだまだ不明な点が 多く, 晾断法や治療は確立されていないのが現 状である.

著者らは近畿大学耳鼻咽缶科の呕喉頭異常感 外来（異常感外来之略す）において昭和 52 年 10 
月より, 咽喉頭異常感の発現機序の解明という 目的亡, 墨性腫瘍をはじめとする重篤な器質的 疾患のスクリーニングのために，小池ら ${ }^{1)}$ が提 唱した診断的治療を行ってきたが，咽喉頭異常 感を訴える患者の中に甲状腺乲患が比較的よく 見出されることから, 咽喉頭異常感の器質的成 因の解明の一端として, 甲状腺疾患之咽喉頭異 常感との関連性について, 甲状腺外来のデータ 一あ併せて検討を試みた。甲状腺疾患をとりあ げたのは，症例数が多いだけでなく，頸部の笑 患であるてと，内分泌関連していること，良 性から悪性まで種々の腫演が存在するととか ら, 咽喉頭異常感の発現にはお㧊いに関連があ るだろうと考えられ，頭頸部外科を扱う耳鼻咽 喉科医が，日常晾療する際に必ず念頭に置か的 ばならない疾患のひとつであるというのに，て れまで詳細は報告や充分な考察がなされていな いためである.

\section{対象ならびに臨床統計}

近畿大学耳鼻咽噭科の異常感外来で报った栶 喉頭異常感を主訴とした患者は，炤和52年10月 より昭和 61 年 6 月の 8 年 9 ケ月の間に 1540 例で
あり，性別では男性596例（38.7\%），女性977 例（61.3\%）之女性に多く，年齢別にみると30 代より50代に多く集中している，乙れらの患者 のうちで, なんらかの器質的疾患を有していた 屯のは 681 例であり, 咽喉頭異常感を主訴とし て来院した患者の $44.2 \%$ にあたる.

また同期間に甲状腺外来において报った甲状 腺疾患の症例は総数で1008例であり，性別で は男性112例（11.1\%）に対して，女性 896 例 (88.9\%) と王倒的飞女性が多い。年柃構成か らみると 30 代より 50 代のうちに 695 例が存在 し，乙れは全体の $68.9 \%$ に相当する.

以下甲状腺聅患之咽椥頭異常感の関速につい て詳しく観察した結果について報告する。なお 異常感外来で実施した診断的治療法ならびに効 果の判定は, 小池ら ${ }^{1)}$ の提唱に従った。

1. 異常感外来における甲状腺疾患

まず異常感外来において报った症例のなか で，甲状腺娭患を有した症例について統計的な 観察を行った。表 1 は咽欲頭異常感を主訴とし て来院した1540例のうち, なんらかの器質的疾 患をむった症例 681 例の詳細な内訳を示してい

表 I 器質的㸻患の内訳

\begin{tabular}{|c|c|c|c|c|}
\hline 咽 喉 頭 炎 & 22例 & 子 & 癌 & 4例 \\
\hline 慢 性副 鼻・腔炎 & 83 & 粗 鷋 & 症 & 4 \\
\hline 慢性甲状腺炎 & 61 & 筋 & 腫 & 4 \\
\hline 舌 砶 桃 肥 大 & 40 & 里 状 腺 & 癌 & 4 \\
\hline 甲 状 腺 結 幯 & 22 & 十二指腸 潰 & 湯 & 3 \\
\hline 肝 機 能 障 害 & 22 & 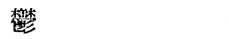 & 病 & 3 \\
\hline 高 血 圧 症 & 19 & 声＼cjkstart带＼cjkstart萎 & 縮 & 3 \\
\hline 声帯結節・ポリープ & 18 & 過 長 茎状突 & 起 & 3 \\
\hline 鼻アレルギー & 15 & 正 中澒 のう & 胞 & 3 \\
\hline 鼻中隔湾曲症 & 10 & 喘 & 息 & 2 \\
\hline 糖 尿 病 & 8 & 脆＼cjkstart桃＼cjkstart術 & 後 & 2 \\
\hline 慢 性 気 管支炎 & 7 & 里 状 腺 術 & 後 & 2 \\
\hline 胃癌 & 5 & 咽＼cjkstart頭＼cjkstart乳＼cjkstart頭 & 腫 & 2 \\
\hline 胃＜wide>潰 & 6 & 啒＼cjkstart頭 & 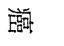 & 2 \\
\hline 慢 性 胃 炎 & 5 & 里状腺 機能低下 & 症 & 2 \\
\hline 乳癌 & 5 & $\begin{array}{l}\text { 食 道 想 } \\
\end{array}$ & 室 & 2 \\
\hline 甲状腺機 能元進症 & 5 & の & 他 & 44 \\
\hline 貧血 & 5 & & & \\
\hline 喉 頭蓋のう胞 & 5 & (咽頭癌, 肺癌, & & \\
\hline
\end{tabular}


る.表からむわかるように最屯多く認められた 笑患は咽喉頭炎であり，大部分は慢性炎症であ る. 次いで多く見出されたのは慢性副鼻腔炎で あり， 3 番目に慢性甲状腺炎がある。 その他下 線を施こした症例はすべて甲状腺に関係した症 例であり，乙れを合計すると96例むある。乙れ は発見された器質的疾患の $14 \%$ 占める。また 同期間の甲状腺疾患が1008例であるから，ての うち約 1 割の症例が咽喉頭異常感を主訴として 米院したてとになる。

次にこの96例中で, 診断的治療を行い, その うえで追跡調査が可能であった症例について検 討した。 甲状腺疾患の内訳は, 慢性甲状腺炎 22 例, 腺腫（のう胞を含む） 7 例, 甲状腺機能六 進症 2 例, 亚急性甲状腺炎, 甲状腺癌, 甲状腺 機能圥進症が各 1 例である. これらの症例の異 常感の訴え方を具体的に問診したところ.「の どがつまっている感じがする」と訴える者が最 あ多く，次いで「のみてみにくい」や「異物感 がある」などの表現をするようだ。診断的治療 の結果を表 2 にまよめた。闸状腺灾患を有する 症例のうち, 診断的治療によって, 著効, 有 効, やや有効の効果を得たものを合計すると56

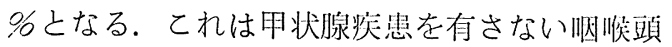
異常感症例の渚効, 有効, やや有効の 3 者を併 せた74\%に比較すると, 甲状異疾患を有する症 例に扔いて, 診断的治療の効果が低いととを示 している．また症例が少いため断定は困難だ が, 表中の甲状腺癌は恶化を示しており, 腺腫 も 7 例中 4 例が無効を示すなど, 腫愓病変に対
する診断的治療の効果は必ずしあよくないとい える.

2.甲状腺外来における咽喉䫓異常感

前述したごとくこの期間に甲状腺外来を受診 した患者は1008例であり，てのうち主な甲状腺 疾患について，各症例数ならびに訴えの中に栶 唝頭異常感と考えられる訴えが存在した症例数 をまとめたものが表 3 である，疾患別では慢性 甲状腺炎が 336 例で最屯多数を占め，その中で 161 例（48.0\%）がなんらかの咽喉頭の異常感 を訴えている。次に単純性び慢性甲状腺腫 165 例では98例（59.3\%），腺腫様甲状腺腫125例で は43例 (34.4\%), 甲状腺結節98例では32例 (32.7\%) で比較的咽喉頭異常感を訴えている 頻度が高く，それに比してバセドウ病，甲状腺 癌に打ける咽喉頭異常感の訴えの比率が各々 $11.5 \% ， 25.7 \%$ とやや低い。 また異所性甲状腺 腫は 4 例と屯舌根部から下咽頭にかけて存在し たため全例咽喉頭異常感を訴えている。いずれ

表 3 主な甲状腺疾患と異常感を訴えた症例数

\begin{tabular}{|c|c|c|}
\hline & 全症例 & 㟟常感症例 \\
\hline 慢性甲状腚炎 & 336例 & 161例 $(48.0 \%)$ \\
\hline 単純性び慢性甲状腺腫 & 165 & $98 \quad(59.3)$ \\
\hline 腺腫様甲状腺腫 & 125 & $43 \quad(34.4)$ \\
\hline バセドウ病 & 104 & $(11.5$ \\
\hline 甲状腺絬節 & 98 & $(32.7$ \\
\hline 甲状腺癌 & 74 & $19 \quad 25.7$ \\
\hline 異所性甲状腺腫 & 4 & $4(100.0)$ \\
\hline 合 & 906 & $369 \quad(40.7 \%)$ \\
\hline
\end{tabular}

表 2 甲状腺疾患における咽喉頭異常感の各疾患別治療成績

\begin{tabular}{|c|c|c|c|c|c|c|}
\hline & 著効 & 有効 & やや有効 & 無効 & 婁化 & 計 \\
\hline 慢性甲状腺炎 & 7 & 5 & 2 & 7 & 1 & 22 \\
\hline 甲 状腺 䤚 & 2 & 0 & 1 & 4 & 0 & 7 \\
\hline 甲状腺機能穴進 & 0 & 0 & 1 & 0 & 1 & 2 \\
\hline 亚急性甲状腺炎 & 0 & 1 & 0 & 0 & 0 & 1 \\
\hline 甲 状 腺 癌 & 0 & 0 & 0 & 0 & 1 & 1 \\
\hline 甲状腺機能低下 & 0 & 0 & 0 & 1 & 0 & 1 \\
\hline 計 & $\begin{array}{c}9 \\
(26 \%)\end{array}$ & $\begin{array}{c}6 \\
(18 \%)\end{array}$ & $\begin{array}{c}4 \\
(12 \%)\end{array}$ & $\begin{array}{c}12 \\
(35 \%)\end{array}$ & $\begin{array}{c}3 \\
(9 \%)\end{array}$ & 34 \\
\hline
\end{tabular}


にしても全症例の $40.7 \%$ がなんらかの咽喉頭異 常感を持っているととになる. 但し上茜の咽咲 頭異常感の訴えは必ずしも主訴という訳ではな く, 詳細な問診の結果, 種々の泝えのなかに咽 喉頭異常感と考えられる症状が，一つでああっ た症例をあげているのであって，前述の異常感 外来で扱った症例とは一致しない症例む存在す るととを付記しておく.

あうひとつの钼察は, 甲状腺咨患の治療に伴 う咽喉頭異常感の変化について実施した。

まず慢性甲状腺炎と単純性び慢性甲状腺腫に おいて，診断的治療を行った群（A群とする） とマイナー・トランキライザーにチラージン S （ $\mathrm{T}_{4}$ ）を加えて治療した群（B群とする）とに 分けて効果判定した。 その結果, 慢性甲状腺炎 では著効, 有効を併せた有効例と無效例は各々 A 群で $67 \%$ と $10 \%$, B 群で $87 \%$ と10\%, 同様に 単純性び慢性甲状腺腫ではA群においては77\% と $8 \%$ ，B群で $83 \%$ と $17 \%$ ありり，慢性甲状腺 炎においては疾患本来の治療法であるチラージ ン Sの投与により，咽喉頭異常悠を軽減させる 効果があることがわかる. 次に手術療法によっ て, 術前と術後の咽喉頭黑常感の変化を倠察し てみたが，乙れは全例において術直後には訴え はなくなるものの, その後の経過睍察ゆに再び 泝えが戻ったり，新えの内容が変化したり，將 には訴えがなくなったりと様々な反応が認めら れ，ての点における明䂨な結諭は得られなかっ た.

最後に甲状腺外来で报った症例について， 疾患別の主泝を検微してみた。慢性甲状腺炎の み「咽喉頭異常感」を主訴とするるとが最む多 く，他疾患はすべて「頸部のしてり」を主訴と することが多いようだ。またバセドウ病の埸 合, 乙の疾患に特有の症状を泝えることが多 く, 「咽喉頭異常感」を主粆とすることは他灾 患に比較して，当然少いようである。

\section{考察}

咽喉頭異常感の発現機序に関しては，従来よ り諸家の研究がなされているが, 器質的成因之
機能的成因のうち垟一な成因からなるものも存 在するだろうが， 2 成因以上の複合成因が裬雑 に絡み合っている場合屯多いように思われる。 従って日常臨床的に診断, 治療が行われる際 は，医侕をしてたいへん困惑させて来た。临家 があげている成因をみてみると，心身症の立場 における心因性の要素4), 内分泌の機能異常8), 自律神経失調 ${ }^{91}$, 唾液分泌低下 ${ }^{10)}$, 鉄欠乏性貧 III [1 ${ }^{11)}$ ，頸椎異常 ${ }^{12)}$ な゙様々である。また三宅 ${ }^{13)}$ はこれらの成因を局所, 全身, 心因性の $3 つ$ の 要素に分類し, 各々が単独または重なり合って いると述べている．てのように多数の成因によ り成立する咽喉韻異常感を报うにあたって，小 池ら ${ }^{114)}$ はスクリーニング法として診断的治療 法を提梋している，われわれも異管感外来にお いて，詔和52年より，このうj法を実施してお り，その結果老踏まえて各隐休統計を行ってい る.またこのデーターは咽唝頭異賞感（症）研 呪会にも提供している，ところで過去に多数の

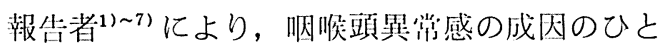
つとして，甲状腺疾腎があげられてきたが，実 際に甲状腺疾蝐之咽喉頭買常感の関連性につ き，詳紃な報点がなされたととはないようだ。 またわれわれのデーターによると，他の報告者 により報告された甲状腺疾腎をむつ咽喉頭異常 感症の患者数はいささか少いようだ。われわれ 屯咽喉頭異常感を訴える患者の中で発見された 哭啠的疾患 681 例のうち 96 例が甲状腺疾患を有 していたことには幾分警いている次第である. しかしこの結果は近戗大学耳鼻咽喉科外来にお いて，異常感外来之甲状腺外来が面密な速絡を とりあって，共に問診ならびに入念な頸部触 診, 甲状腺の形態的, 機能的検查を行った結果 であり，咽喉頭異常感を报う際に，甲状腺に限 っこてとでなく，悪性腫瘍をはじめとする重篤 な疾患は言うに限らず，他の潜在する様々な器 質的疾患の検索の重要性を, 改めて認識させら れた。 以下著者らが臨床データ一から得られた 統計結果について考察を加えた。

まず作秢構成についてみると，咽喉頭異常感 
を訴える患者は30代より50代に多く，乙の傾向 は甲状腺疾患とくに慢性甲状腺炎を有する患者 にも同様のことがいえる．乙の慢性甲状腺炎の 年龄構成については，第24回日本内分泌学会西 部々会において，ワークショップとしてとりあ げられた際の班研究において，当科に拈ける年 齢構成とほぼ同様の結果が報告されている ${ }^{15)}$. 性差については，咽喉頭異常感を訴える患者む 甲状腺疾患々者屯其に, 女性に多い。従って年 齢, 性差に执いて, 雨患者は30代より50代の女 性に多いことで一致している.

次に症状の点では，甲状腺疾患々者の場合主 訴として訴える症状は「頸部のしてり」が压倒 的に多いが，詳細な問診をしてみると，咽喉頭 異常感を持つむのも少くない. 但しバセドウ氏 病については，その特徽的な症状が前面に強く 出るため, 当然ながら咽喉頭異常感を訴えるこ とは少いようである. 慢性甲状腺炎では約半数 が咽喉頭異常感を主訴としているが，てれは内 科, 外科に扔いて検㣨された症状の頻度順 ${ }^{15)}$ 一致していない，てれは耳鼻咽喉科の特徵が表 われていると考えている.

咽喉頭異常感を主訴として来院する患者の甲 状腺腫は，だいたいにおいて本人の気付かない 程度の比較的小さな場合が多く, 診察に際して は入念な頸部触猃が重琶である．熟練した医師 による触診で, 甲状腺腫の 9 制は発㒻が可能 であり，エコーグラム，シンチグラムを用いれ ば，発見率は $100 \%$ に近づくあのである. 一般 において甲状腺の診断㭘查には，甲状腺ホルモ ンの測定がなされ，「異常がない」という判断 が下されがちだが, 前述の形態学的な検査に合 わせて，サイログロブリン抗体やマイクロゾー ム抗体の免疫反応をみる検查により, 慢性甲状 腺炎の診断が可能となる，また組織診断の決め 手として, 穿刺吸引細胞診は手軽で, 診断泑に おいても 9 割を越しているので, 非常に有用な 手段といえる. 従って咽喉頭異常感症例の診察 に执いても，まず入念な問診・触診を行い，異 常を感じるなら単に甲状腺ホルモンの测定にと
どまらず，乙れらの検査を適宜施行する必要が ある。

治療については，結節性病変の場合は腺腫様 甲状腺腫や慢性甲状腺炎の結節状变化である症 例を除いて，手術療法にたよらざるを得ない。 なぜなら薬物療法により根治する症例は限られ て抢り, 常に増殖性の問題や悪性腫瘍の存在の 可能性があることによる。び慢性甲状腺腫の場 合, 機能異常が存在するなら，その是正が必要 だが，そうでない場合，とくに慢性甲状腺炎や 単純性び慢性甲状腺腫については，診断的治療 が有効な場合がかなりある．また原疾患の治療 を考慮してチラージン S な゙の甲状腺ヨード剂 の投与を加えると更に効果はあがるようだ。 こ れは特に慢性甲状腺炎について顕著である.

以上述べてきたてとより甲状腺疾患は咽喉頭 異常感発現の一成因となっているととは充分考 えられる，とくに甲状腺腫が結節性病変を呈す る侍よりもび慢性病変に著明であり，乙のとと は気管前方にあたる甲状腺峡部の腫大が関与し ているとも考えられる. 小池 ${ }^{2)}$ は慢性甲状腺炎 による咽哫頭異常感には，甲状腺峡部切除が有 効であると報告しており，われわれあ数例に施 行したところ，良好な結果を得ている，但し咽 喉頭異常感を訴える患者の甲状腺腫は必ずしも 大きくないことが多く，単に物理的見地からの みで説朋することはできない，河辺ら31 は咽喉 頭異常を訴える患者の約 $20 \%$ に ${ }^{131} \mathrm{I}$ 摂取率の低 下を認めたと報告している。 われわれむバセド ウ病においても咽喉頭異常感が存在するととを 確認している．乙のてとから甲状腺機能屯関与 している可能性が考えられる。 また慢性甲状腺 炎においては甲状腺腫も極めて小さく，機能屯 正常なものが多く存在する事春より，他の原 因，例えば頸部の複雑な自律神経系の関与など

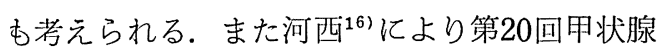
外科検討会において，慢性甲状腺炎の患者に は，34.5\%に抑うつ症例が存在したとの報告が なされており, 精神病理学的な見地も検討され る必要がある. 


\section{まとめ}

咽喉頭異常感を有する患者の中には，甲状腺 疾患を有するものが決して少くない，そこで耳 鼻咽喉科医の立場として，このととを念頭にお き，問診はいうに及ばず，入念な頸部蟲診やそ の他の検査を適宜実施すべきである，また慢性 甲状腺炎之咽喉頭異常感の関连性は強く, 部断 的治療とともに甲状腺ホルモン療法が効果をあ げることが多い。

\section{参考文献}

1）小池靖夫, 戸田雅克, 太田文彦, 他：咽喉頭異常 感症に対する讋断的治燎. 耳鱼臨床 72 : 1499〜 1506, 1979.

2) Koike Y, Morimoto M and Honjyo I : Laryngeal complaints and voice disorders due to goiter and their operative treatment. Record of 11 th International Congress of $\mathrm{Br}$ onchoesophagology. pp 16 20, Hakone, Japan, 1965.

3 ）河辺䉝孝, 近藤 隆：咽喉頭食道異常感に関する 臨床的観察一とくに異常感症患者の腺機能につい て一，日気食会報 $18: 54 \sim 58 ， 1967$.

4) 日野原正, 他：咽㑨頭異常感について一心身症の 立場汃ら一耳展 $10: 265 \sim 272,1967$.

5 ) 戸川 清：咽喉頭異常感の治狝. 耳䌹臨床 67 : 925 927, 1974.

6）仁木 宏, 小池聰之, 松浦健次郎, 他: くび肩凝 り・咽喉頭異常感症に対する上頸部神経節遮断注
射の効果. 耳鼻臨床 $69: 1291 \sim 1299,1976$.

7 ) 佐藤武男：咽喉頭異常感症（とくに癌との鑑別）. 耳饙臨床 $70: 1004 \sim 1006,1977$.

8 ）三宅 弘：咽喉頭部異常感症における卵胞, 黄 体，性腺刻激ホルモン。目䒚 $72: 876 \sim 883$, 1969.

9 ) 五十嵐博之：咽喉頭異常感症（主として自律神経 系へのアプローチ). 耳具臨床 $70: 1007 \sim 1010$, 1977.

10）戸川川 清：咽喉頭部異常感と嗂液分泌障踳. 耳喉 $40: 209 \sim 212,1968$.

11）小野真孝：咽・喉頭, 食道異常感に関する研究. 日耳厸 $63: 778 \sim 793,1960$.

12）河本和友：咽㑨頭異常感に関する考察. 日気食会 報 $14: 104 \sim 105 ， 1963$.

13）三宅 弘：咽喉頭部異常感症の成立に関連する全 身的要因の考察. 耳喉 $40: 187 \sim 192,1968$.

14）小池靖夫, 戸田雅克, 北野康雄, 他：ノイチーム とクロキサゾラムによる咽喉頭異常感症の鑑別. 基礎と臨佅 $15: 463 \sim 467,1981$.

15）鳥塚筦爾：慢性甲状腺炎の病像に関しての各種調 査つき集計成績について。 ホルモンと臨床 25 ： 471 479, 1977.

16）河西信勝：慢性甲甲状腺炎と抑うつ状蓓. 第10回甲 状腺外科㭘討会抄録集（信州大学第 2 外科). 34 頁, 松本, 1987 .

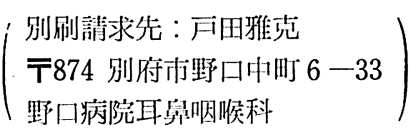

